KORNEL MUSIAL

ORCID: 0000-0002-8405-5062

Uniwersytet Wrocławski

kornelmusialbc@gmail.com

\title{
Analiza sytuacji zawodowej funkcjonariuszy Państwowej Straży Pożarnej
}

https://doi.org/10.19195/2083-7763.10.13

\section{Abstrakt}

Poczucie bezpieczeństwa jest jedną z głównych potrzeb człowieka. Pomimo rozwoju cywilizacyjnego i postępującej urbanizacji w XXI wieku jednostki narażone są na wiele zagrożeń, które muszą być skutecznie niwelowane przez grupy dyspozycyjne społeczeństwa polskiego i ich profesjonalnie przygotowaną do tego kadrę. Autor charakteryzuje Państwową Straż Pożarną, czyli paramilitarną formację systemu bezpieczeństwa państwa. Ukazuje jej bogatą, lecz zawiłą historię, a następnie opisuje społeczny wzór strażaka. Drugą część artykułu jest analiza badań ilościowych. Autor weryfikuje poziom satysfakcji strażaków z wykonywanej przez nich roli zawodowej.

Słowa kluczowe: Państwowa Straż Pożarna, grupy dyspozycyjne, paramilitarna grupa dyspozycyjna, socjologia grup dyspozycyjnych, socjologia pracy

\section{Wstęp}

Pomimo rozwoju cywilizacyjnego i postępującej urbanizacji w obecnych czasach jednostki narażone są na wiele zagrożeń, które muszą być skutecznie niwelowane przez grupy dyspozycyjne społeczeństwa polskiego i ich profesjonalnie przygotowaną do tego kadrę. Jedną z grup wykazującą się dużą dyspozycyjnością jest Państwowa Straż Pożarna, której struktury organizacyjne zostały ujęte w działalność o charakterze formacji paramilitarnej zapewniającej podstawową potrzebę człowieka, jaką jest bezpieczeństwo. Strażacy odgrywają istotną rolę w systemie społecznym, niwelując ryzyko rozpowszechniania się ognia oraz walcząc z klęskami żywiołowymi. Fenomen ich działalności stanowi chęć do poświęcenia 
się na rzecz innych lokalnych społeczności, w których żyją i realizują swoje plany, zarówno zawodowe, jak i prywatne. W artykule zostaną zaprezentowane uwarunkowania historyczne i teoretyczne Państwowej Straży Pożarnej oraz analiza empiryczna badań przeprowadzonych na funkcjonariuszach PSP.

\section{Potrzeba bezpieczeństwa i geneza pożarnictwa polskiego}

Poczucie bezpieczeństwa jest jedną z głównych potrzeb człowieka. Stan ten analizowany był przez wielu badaczy wywodzących się z różnych dyscyplin naukowych, w tym głównie socjologów, psychologów, andrologów i biologów. Ilekroć analizowana jest kwestia egzystencjalnych potrzeb człowieka, rozważania autorów stanowi lub wnikliwie dopełnia opracowana przez Williama Thomasa lub Abrahama Maslowa teoria modelu psychologicznego i motywacyjnego odwołująca się do konkretnej hierarchii potrzeb. Dominującą formą przekazu podczas edukacji szkolnej lub analizy stanu umożliwiającego jednostce swobodę działania stała się graficzna piramida zawierająca potrzeby wyższego i niższego rzędu ${ }^{1}$. Najistotniejszymi i jednocześnie niezbędnymi do prawidłowego funkcjonowania człowieka są potrzeby fizjologiczne (jedzenie, wypoczynek, sen) oraz natury psychicznej i emocjonalnej, czyli konieczność eliminacji zagrożeń, sprawiedliwości czy stabilności własnego bytu, które należą do potrzeb bezpieczeństwa (drugiego rzędu). Stopniowe niwelowanie bezpiecznego umiejscowienia jednostki zakłóca jej poprawne funkcjonowanie w życiu społecznym. Aby sprostać wszelkiego rodzaju trudnościom i występującym od zarania dziejów zróżnicowanym zagrożeniom pojedyncze osoby zaczęły łączyć się i tym samym organizować twory typowo społeczne, a mianowicie grupy społeczne, których zadaniem była określona dbałość o dane terytorium. W późniejszym etapie formacje te przybierały postać grup wysoce sformalizowanych o ekskluzywnym charakterze. Obecnie możemy wskazać zjawiska wysoce szkodliwe dla pojedynczych osób, jak i całej wybranej społeczności. Rozwój cywilizacyjny i infrastrukturalny dostarcza również wielu zagrożeń wcześniej niewystępujących. Spośród tradycyjnych należy zwrócić uwagę na wszelkie konflikty (w tym wojny), terroryzm i różnego rodzaju klęski żywiołowe (na przykład powodzie), których jednostki działające indywidualnie nie będą w stanie przezwyciężyć. W celu niwelowania tego typu niebezpieczeństw powołano specjalistyczne formacje, które określane są jako grupy dyspozycyjne będące obszarem zainteresowań badaczy z pogranicza socjologii grup dyspozycyjnych i bezpieczeństwa. Samo pojęcie dyspozycyjności wywodzi się z języka łacińskiego określanego jako dispono, oznaczające 'dysponowanie', 'porządkowanie', ale również 'zastosowanie'. Wielu tych określeń możemy teraz użyć przy analizie zbiorowych grup społecznych, które służą zarówno systemowi państwowemu, jak i jego społeczeństwu, a owa dyspozycyjność

1 A. Maslow, Motywacja i osobowość, przeł. J. Radzicki, red. T. Rzepa, Warszawa 2009, s. 115-119. 
odznacza się gotowością do działań lub poświęceń na rzecz innych. Muszą to być zatem zamknięte grupy zadaniowe o określonej strukturze, charakteryzujące się zaplanowanym działaniem zespołowym, których szeregi wypełnia grupa profesjonalistów. Obecnie, jak podkreśla Jan Maciejewski, na terenie Rzeczypospolitej Polskiej funkcjonują w obszarze bezpieczeństwa grupy dyspozycyjne o charakterze militarnym, paramilitarnym, cywilnym oraz ochotniczym ${ }^{2}$.

Analizę historycznych uwarunkowań polskich organizacji strażackich warto rozpocząć od okresu średniowiecza i renesansu. $W$ epoce średniowiecznej, jak słusznie zauważył Janusz Popis, nie istniały plany architektoniczne, domy stawiano, używając wyłącznie drewna, a ulice były ciasne i często ślepe ${ }^{3}$. Wymienione czynniki sprzyjały powstawaniu oraz rozpowszechnianiu się działań ogniowych. Tragiczne w skutkach wydarzenia występowały w wielu regionach Polski, jednak największa plaga zaznaczyła się w Krakowie: 1241 roku: najazd tatarski — spalona została większość miasta - i 44 lata później pożar w trakcie bitwy nad Rabą. Aby zminimalizować straty ponoszone w trakcie wojny lub przez nieprzezorność ludzi w XIV wieku krakowska rada miejska ustanowiła zapiski zwane „Walkirjami”, w których zawarto wytyczne odwołujące się do obronności wobec ognia ${ }^{4}$. Nieco później porządki ogniowe zostały zapisane w Poznaniu i Warszawie. Zaczęto również wyciągać konsekwencje wobec osób, które w sposób umyślny rozpowszechniały ogień, w Warszawie wydano dekret zakazujący budowania domów drewnianych, a te już postawione musiały zostać zmodyfikowane. Przełom nastąpił w XVII wieku, gdy udoskonalono dotychczasowe przepisy i wprowadzono regulacje, których treść odnosiła się do formy prewencyjnej przeciwko zagrożeniom pożarowym. Wydane regulacje zawierały między innymi następujące wytyczne:

- wprowadzono obowiązkowe kontrole przeciwpożarowe,

- opisano system alarmowy w trakcie wystąpienia pożaru,

- określono czynności, jakie należy podjąć w czasie pożaru,

—zawarto sankcje wobec osób nieprzestrzegających przepisów porządkowych ${ }^{5}$.

W XVIII wieku w związku z upadkiem Rzeczypospolitej i jej rozbiorem przez Austrię, Prusy i Rosję kwestie ochrony przeciwpożarowej różniły się między sobą, ponieważ w każdym z zaborów obowiązywały inne regulacje. W zaborze austriackim wydano następujące dokumenty prawne: ustawę ogniową (1768), krajową ustawę miejską (1891), ustawę o policji ogniowej $(1910)^{6}$. Ponadto na tych

\footnotetext{
2 J. Maciejewski, Grupy dyspozycyjne - analiza socjologiczna, Wrocław 2012, s. 50.

3 J. Popis, Historia pożarnictwa w Polsce, [w:] Kultura bezpieczeństwa. Nauka - praktyka - refleksje, red. Y. Boshytskyi et al., Kraków 2013, s. 154.

${ }^{4}$ M. Prokopp, Historia bezpieczeństwa ogniowego w Królestwie Polskim w latach 1831-1855, Warszawa 1934, s. 9.

${ }^{5}$ J. Popis, op. cit., s. 155-156.

6 D. Falecki, Zarys rozwoju ochrony przeciwpożarowej w Polsce do 1992 r., [w:] Czerwona księga pożarów, t. 1, red. P. Guzewski, D. Wróblewski, Józefów 2016, s. 39.
} 
terenach, a uściślając - w Krakowie, powstała pierwsza ochotnicza oraz zawodowa straż pożarna ${ }^{7}$. Szacuje się, że w Galicji było aż 1466 oddziałów straży pożarnej ${ }^{8}$.

W zaborze pruskim organy policyjne wydawały obowiązujące regulacje przeciwpożarowe, $\mathrm{z}$ czego charakter główny miała ustawa z 1883 roku o ogólnym zarządzie $\mathrm{kraju}^{9}$. Oprócz ochotniczych i zawodowych straży pożarnych powołano obowiązkowe jednostki, które zasilano mieszkańcami gminy. Dostrzeżono również zagrożenia, na jakie narażone są strażacy w trakcie akcji ratunkowych. W tym celu w 1864 roku w Poznaniu powołano Krajową Kasę Ubezpieczeń Strażaków od Wypadków, która wypłacała stosowne rekompensacje finansowe strażakom oraz ich rodzinom, jeżeli ucierpieli oni w trakcie wykonywania obowiązków zawodowych ${ }^{10}$.

Zabór rosyjski był o wiele mniej sformalizowany, gdyż kwestie ochrony przeciwpożarowej nie były ustanowione przepisami prawa. Wysiłek w celu założenia zawodowej straży podjął Jan Rudnicki z Warszawy. Dzięki niemu na początku 1836 roku została powołana Straż Ogniowa ${ }^{11}$. W 1864 roku powołano Ochotniczą Straż Pożarną w Kaliszu, a następne formacje zaznaczyły swą obecność w Częstochowie (1871 rok) i Kielcach (1874 rok) ${ }^{12}$. Warto zaznaczyć, że w 1900 roku w Królestwie Polskim funkcjonowało 128 straży pożarnych, a w 1901 roku ukazało się pierwsze czasopismo strażackie ${ }^{13}$.

Odzyskanie przez Polskę niepodległości w 1918 roku dawało nadzieje na samodzielne uformowanie profesjonalnej straży bez udziału okupantów. Proces jednak był trudny i czasochłonny ze względu na różnice prawne obowiązujące w trakcie zaborów. Z tego względu w 1921 roku w Warszawie zorganizowano Zjazd Delegatów Straży Pożarnych Rzeczypospolitej Polskiej, podczas którego „powołano Główny Związek Straży Pożarnych Rzeczypospolitej Polskiej jako organizację ogólnopolską, która zrzeszała wszystkie dzielnicowe związki straży pożarnych"14. Od tej pory był to najwyższy organ strażacki, który reprezentował wszystkich funkcjonariuszy. Następną ważną kwestią regulującą przepisy przeciwpożarowe było uchwalenie w 1934 roku ustawy, która wprowadzała pewną świeżość i harmonię, ponieważ należy zaznaczyć, że była to pierwsza próba aktualizacji starych przepisów z okresu zaborów. Ponadto postawiono na rozwój kadry strażackiej i zaczęto organizować szkolenia dla szeregowych, podoficerów i funkcjonariuszy mających wyższe stopnie. Nie zapomniano również o rozwoju

\footnotetext{
7 J. Popis, op. cit., s. 162.

8 D. Falecki, op. cit., s. 39.

9 Ibidem, s. 163.

10 E. Burzyński, Z. Radwański, Dzieje ochrony przeciwpożarowej w Polsce, Warszawa 1964, s. 46.

11 https://www.straz.gov.pl/panstwowa_straz_pozarna/w_okresie_zaborow (dostęp: 8.04.2019).

12 D. Falecki, op. cit., s. 40.

13 Ibidem, s. 41.

14 J. Popis, op. cit., s. 165.
}

Forum Socjologiczne 10, 2020

(C) for this edition by CNS 
technologicznym oraz zmotoryzowaniu straży w celu zapewnienia specjalistycznego sprzętu, którego nie musiały już przewozić konie ${ }^{15}$.

W trakcie okupacji hitlerowskiej polscy strażacy odznaczyli się niemałą odwagą. Wszystkie jednostki w Generalnym Gubernatorstwie były podporządkowane władzom niemieckim, jednakże nie utrudniło to działalności konspiracyjnej w oddziałach strażackich. Funkcjonariusze dumnie starali się służyć społeczeństwu oraz utworzyli tajną organizację — Strażacki Ruch Oporu „Strzała”, który organizował szkolenia z zakresu działań przeciwpożarowych oraz wojskowych ${ }^{16}$.

Po zakończeniu drugiej wojny światowej został reaktywowany Związek Straży Pożarnych RP, a w 1950 roku Sejm przyjął ustawę o ochronie przeciwpożarowej i jej reorganizacji. Organem naczelnym była Komenda Główna Straży Pożarnej, której podlegały komendy wojewódzkie, powiatowe i miejskie. W tym samym roku nastąpiła nominacja na pierwszego komendanta straży pożarnej. Zwrócono również uwagę na funkcjonujące już od dawna w społeczeństwie polskim ochotnicze straże pożarne, których działalność została prawnie uregulowana w 1956 roku. Ponadto dołożono wszelkich starań do poszerzenia oferty edukacyjnej ośrodków szkoleniowych, ustalono ogólnopolski telefoniczny numer alarmowy, przeprowadzono wiele projektów przeciwpożarowych o charakterze profilaktycznym oraz utworzono pierwszą szkołę wyższą kształcącą kadrę oficerską ${ }^{17}$.

Nowy rozdział w historii pożarnictwa rozpoczął się po transformacji ustrojowej, kiedy przyjęto dwie ustawy:

- ustawę z dnia 24 sierpnia 1991 roku o ochronie przeciwpożarowej,

— ustawę z dnia 24 sierpnia 1991 roku o Państwowej Straży Pożarnej.

Dnia 1 lipca 1992 roku powołano „Państwową Straż Pożarną jako zawodową, umundurowaną i wyposażoną $\mathrm{w}$ specjalistyczny sprzęt formację, przeznaczoną do walki z pożarami, klęskami żywiołowymi innymi miejscowymi zagrożeniami”"18.

\section{Charakterystyka struktury organizacyjnej Państwowej Straży Pożarnej i społecznego wzoru funkcjonariusza PSP}

Działalność i główne zadania Państwowej Straży Pożarnej (dalej: PSP) zostały szczegółowe opisane w ustawie. Możemy wyróżnić jej następujące interdyscyplinarne zadania:

15 D. Falecki, op. cit., s. 44-47.

16 Ibidem, s. 50.

17 J. Popis, op. cit., s. 167-169.

18 Ustawa z dnia 24 sierpnia 1991 roku o Państwowej Straży Pożarnej, art. 1.1. (Dz.U. z 1991 r. Nr 88, poz. 400), http://prawo.sejm.gov.pl/isap.nsf/download.xsp/WDU19910880400/U/D19910400Lj.pdf (dostęp: 10.04.2019). 
— identyfikacja występujących zagrożeń,

- organizacja i kierowanie akcjami ratowniczymi w trakcie wystąpienia na danym obszarze pożaru, klęsk żywiołowych lub innych zagrożeń,

— współpraca z innymi grupami dyspozycyjnymi,

— organizacja szkoleń lub innych form edukacyjnych dla kadry PSP w celu zapewnienia społeczeństwu fachowej pomocy,

- działalność naukowo-badawcza w zakresie bezpieczeństwa,

- wykonywanie zadań, które na podstawie umów z innymi państwami są kluczowe dla naszego kraju (art. 1 ustawy o PSP).

Działania strażaków zmierzające do redukcji i niwelowania zagrożeń metropolitalnych wymagają bacznej obserwacji środowiska i specjalistycznych szkoleń kadry, które, jak podkreśla Małgorzata Stochmal, są bardzo kosztowne z punktu widzenia zarówno finansowego, jak i organizacyjnego. Warto również zwrócić uwagę na opracowany system współpracy między grupami dyspozycyjnymi z sektora militarnego, paramilitarnego, cywilnego lub ochotniczego w celu efektywnego przeprowadzenia akcji ratowniczych. Wszelka kooperacja wymaga czasami działań międzynarodowych, które - jak przypuszczają badacze zaangażowani w problematykę ratownictwa - rozpoczęly się 1988 roku $\mathrm{w}$ Armenii ${ }^{19}$. Kraj ten musiał się wówczas uporać z dotkliwym trzęsieniem ziemi. Przełomowym momentem dla Polski było wstąpienie do Unii Europejskiej (dalej: UE) i tym samym ratyfikowanie aktów prawnych Wspólnotowego Mechanizmu Ochrony Ludności, co też zobowiązuje nasz kraj do udzielania natychmiastowej pomocy krajom zrzeszonym w UE i spoza jej obrębu, jeżeli taka konieczność nastąpi. Należy jednak wskazać, że poza wszelką obligatoryjnością Państwowa Straż Pożarna realizuje projekty, których celem jest współpraca transgraniczna wyznaczająca na przykładzie projektu „Bezpieczne Pogranicze” realizowanego przez Republikę Czeską i Polskę, między innymi przez obopólną wymianę doświadczeń czy ulepszanie systemu reagowania ${ }^{20}$. W strukturze PSP możemy także wyróżnić dział odpowiadający za działalność naukowo-badawczą. Działalność kontrolna $\mathrm{w}$ zakresie przestrzegania przepisów przeciwpożarowych zainicjowała powstanie Rady Naukowo-Technicznej składającej się z funkcjonariuszy reprezentujących poszczególne komendy, osób odpowiadających za oddziały szkoleniowe i naukowe oraz specjalistów spoza struktury Państwowej Straży Pożarnej, których obecność jest szczególnie ważna, gdyż, jak zauważają Marek Kowalski i Dariusz Wróblewski, ukazują oni w Radzie czynniki mające na celu

19 R. Socha, S. Sulenta, Zarzadzanie kryzysowe a działania międzynarodowe Państwowej Straży Pożarnej, „Zeszyty Naukowe Politechniki Śląskiej Seria Organizacja i Zarządzanie” 2016, z. 87, s. 386.

20 http://straz.wroclaw.pl/bezpieczne-pogranicze/ (dostęp: 10.04.2019). 
wzbogacenie prowadzonych w jej ramach dyskusji o zagadnienia istotne w kontekście rozwoju ochrony przeciwpożarowej, a które na co dzień mogą nie być dostrzegane przez osoby pełniące służbę w jednostkach organizacyjnych PSP ${ }^{21}$.

Po omówieniu głównych zadań Państwowej Straży Pożarnej należy wskazać sam stopień organizacyjny PSP (wykres 1).

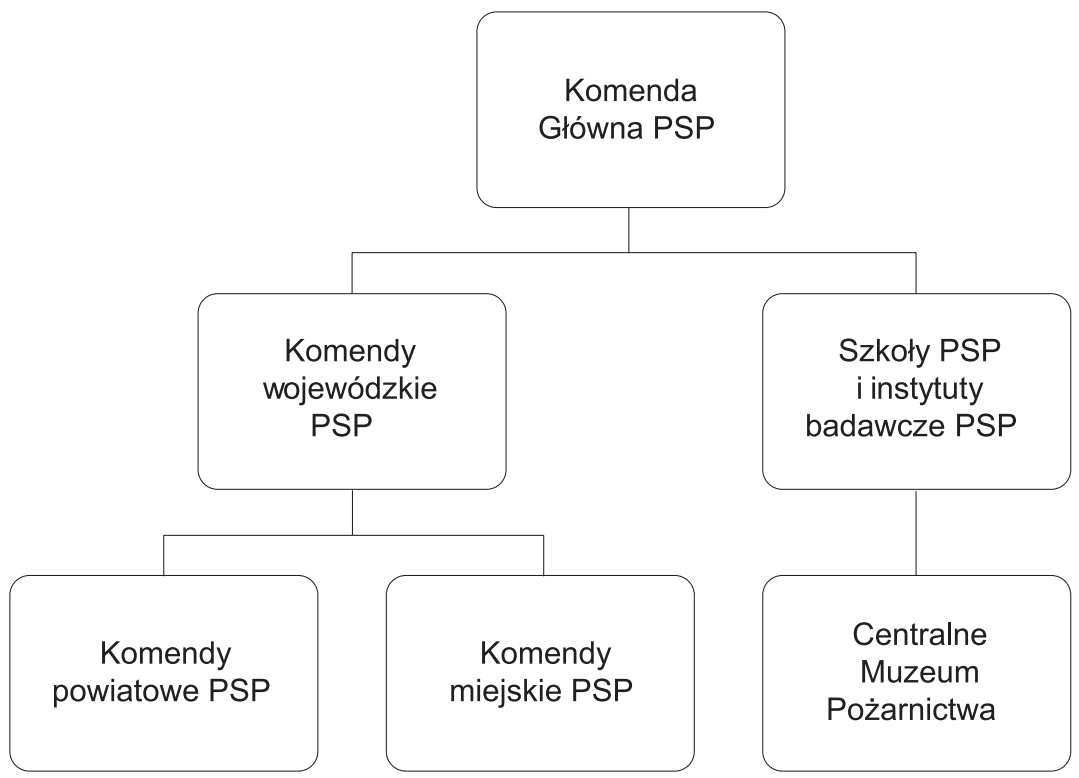

Wykres 1. Stopień organizacyjny PSP

Źródło: ustawa z dnia 24 sierpnia 1991 roku o Państwowej Straży Pożarnej, art. 8.1. (Dz.U. z 1991 r. Nr 88, poz. 400$)$.

Stopień organizacyjny PSP jest zgodny z wytycznymi administracji publicznej w kwestii obowiązującej hierarchii w służbach mundurowych. Dowództwo naczelne mieści się w kompetencjach Komendy Głównej. Prezes Rady Ministrów za pośrednictwem wniosku składanego przez Ministra Spraw Wewnętrznych i Administracji powołuje oraz odwołuje Komendanta Głównego. W kompetencjach Ministra Spraw Wewnętrznych i Administracji mieści się powoływanie oraz odwoływanie na wniosek Komendanta Głównego jego zastępców oraz komendantów jednostek na szczeblu wojewódzkim ${ }^{22}$. Szczegółowe zasady działal-

${ }^{21}$ M. Kowalski, D. Wróblewski, Działalność badawczo-rozwojowa w funkcji realizacji misji, wizji i strategii rozwoju PSP, [w:] Bezpieczeństwo i technika pożarnicza, t. 4, red. M. Kowalski, D. Wróblewski, Józefów 2012, s. 11-12.

22 A. Warmiński, Zadania i organizacja Państwowej Straży Pożarnej w zakresie ochrony przeciwpożarowej, „Doctrina: Studia społeczno-polityczne” 2009, nr 6, s. 292.

Forum Socjologiczne 10, 2020

(C) for this edition by CNS 
ności Komendy Głównej ujęto w statucie Komendy Głównej Państwowej Straży Pożarnej (dalej: Komenda Główna) ${ }^{23}$.

Następnymi jednostkami, które są komponentem w strukturze hierarchicznej PSP, są komendy wojewódzkie. Jest ich szesnaście, zatem widoczny staje się element zgodny z obowiązującym podziałem administracyjnym RP. Funkcjonowanie komend wojewódzkich określają wewnętrzne regulaminy organizacyjne. Zakres obowiązków należących do zatrudnionej w niej kadry jest szeroki, ponieważ odnoszą się one do kwestii zarówno finansowych: planowanie budżetu komendy wojewódzkiej, jak i organizacyjnych: wdrażanie innowacyjnej technologii w zakresie ochrony przeciwpożarowej, współpraca z innymi jednostkami oraz kontrola jednostek podlegających, rozpatrywanie wniosków i skarg (zarówno obywateli, jak i innych instytucji ${ }^{24}$.

Komendy powiatowe i miejskie charakteryzuje szybka reakcja w trakcie wystąpienia klęsk żywiołowych lub zagrożeń miejscowych ${ }^{25}$. Ich obowiązkiem staje się organizowanie jednostek ratowniczo-gaśniczych „na obszarze powiatu, dysponowanie oraz kierowanie siłami i środkami systemu poprzez swoje stanowisko kierowania oraz organizowanie i prowadzenie akcji ratowniczej" 26 . Są one trzonem i podstawą struktury organizacyjnej PSP ze względu na podejmowane działania. Ich głównym zadaniem jest niwelowanie czynników zagrażających społeczeństwu. komendant miejski PSP jest zobowiązany do kierowania swą instytucją, zarządzania kadrą przeznaczoną do prowadzenia akcji ratowniczych oraz doskonalenia systemu pożarniczego między innymi przez prowadzenie szkoleń dla strażaków ochotników z OSP ${ }^{27}$. W 2017 roku na obszarze Polski funkcjonowało 335 komend powiatowych/miejskich Państwowej Straży Pożarnej oraz 496 jednostek ratowniczo-gaśniczych $\mathrm{PSP}^{28}$.

Ważne funkcje w zakresie działalności edukacyjnej i rozwojowej w Państwowej Straży Pożarnej pełnią szkoły PSP: siedemnaście ośrodków szkoleniowych działających przy wojewódzkich komendach PSP, szkoła PSP w Bydgoszczy kształcąca podoficerów, trzy szkoły kształcące aspirantów PSP w Krakowie, Częstochowie oraz Poznaniu, Szkoła Główna Służby Pożarniczej w Warszawie ${ }^{29}$ i Centrum NaukowoBadawcze Ochrony Przeciwpożarowej im. Józefa Tuliszkowskiego - Państwowy

23 Rozporządzenie Prezesa Rady Ministrów z dnia 15 września 1999 roku w sprawie nadania statutu Komendzie Głównej Państwowej Straży Pożarnej, \$ 4.1. (Dz.U. Nr 75 poz. 842 i 843), http:// prawo.sejm.gov.pl/isap.nsf/DocDetails.xsp?id=WDU19990750843 (dostęp: 13.04.2019).

${ }^{24}$ Regulamin organizacyjny Komendy Wojewódzkiej Państwowej Straży Pożarnej we Wrocławiu, $\$ 9$, http://bip.straz.wroclaw.pl/index.php?id=207 (dostęp: 14.04.2019).

25 http://www.kmpspruda.pl/zadania (dostęp: 15.04.2019).

26 A. Warmiński, op. cit., s. 296.

27 D. Riegert, M. Strzyżewska, Państwowa Straż Pożarna, [w:] Czerwona księga pożarów: wybrane problemy pożarów oraz ich skutków, red. P. Guzewski, D. Wróblewski, Józefów 2016, s. 88.

28 Biuletyn Informacyjny Państwowej Straży Pożarnej za rok 2017, s. 11, https://www.straz.gov. $\mathrm{pl} /$ aktualnosci/biuletyny (dostęp: 15.04.2019).

${ }^{29}$ https://www.straz.gov.pl/kontakt/szkoly_pozarnicze2WAwQhc (dostęp: 16.04.2019). 
Instytut Badawczy, którego działalność określa statut zatwierdzony przez Ministra Spraw Wewnętrznych i Administracji. Do jego głównych zadań należy: działalność badawcza, czyli organizacja badań i analiza ich wyników, działalność wydawnicza i promowanie edukacji doktoranckiej ${ }^{30}$.

Kolejną i zarazem ostatnią główną jednostką systemu Państwowej Straży Pożarnej jest Centralne Muzeum Pożarnictwa w Mysłowicach, które powołano w 1975 roku i jest istotnym kontekstem historycznym i dorobkowym pożarnictwa polskiego. W tymże obiekcie są ponad cztery tysiące rekwizytów zabytkowych, między innymi konna drabina, lotniskowy samochód z 1973 roku oraz obowiązujące w przeszłości mundury PSP i OSP ${ }^{31}$.

Państwowa Straż Pożarna należąca do paramilitarnego systemu bezpieczeństwa państwa odznacza się strukturą hierarchiczną i wysokim stopniem profesjonalizmu. Funkcjonariusze, którzy zostali dokładnie przeszkoleni do roli, którą muszą odgrywać w systemie PSP, niwelują zagrożenia występujące na terenie naszego kraju. Andrzej Warmiński pisze, że usytuowanie geograficzne Polski jest dla nas bardzo korzystne, ponieważ nie doświadczamy tragedii związanych z erupcjami wulkanicznymi lub trzęsieniami ziemi ${ }^{32}$. W związku z tym strażacy muszą podejmować akcje ratownicze podczas najczęściej występujących na terenie RP zagrożeń: „pożary, powodzie i zatopienia, katastrofy komunikacyjne i budowlane, wybuchy gazów, przypadki wycieków substancji i środków chemicznych"33. Wyzwania, jakie są stawiane PSP, często wymagają wspomnianej już współpracy na tle lokalnym, krajowym lub międzynarodowym pomiędzy jednostkami PSP oraz innymi grupami dyspozycyjnymi. Ustawa z dnia 24 sierpnia 1991 roku o ochronie przeciwpożarowej jasno określa, które instytucje odpowiedzialne są za niwelowanie zagrożeń zarówno pożarowych, jak i innych miejscowo występujących.

Najważniejszą rolę w strukturze Państwowej Straży Pożarnej odgrywają wykwalifikowani funkcjonariusze, którzy przebyli długą drogę, aby nabyć stosowne kompetencje do pracy $\mathrm{w}$ niniejszej paramilitarnej grupie dyspozycyjnej. Podstawowymi warunkami, jakie musiał spełnić każdy kandydat to między innymi posiadanie obywatelstwa polskiego, niekaralność oraz pozytywny wynik postępowania kwalifikacyjnego, na który nakładają się cztery etapy:

1. złożenie stosownych dokumentów i ich analiza przez wytypowane osoby z PSP,

2. przystąpienie do testu fizycznego,

${ }^{30}$ Rozporządzenie Ministra Spraw Wewnętrznych i Administracji z dnia 15 maja 2017 roku w sprawie zatwierdzenia statutu Centrum Naukowo-Badawczego Ochrony Przeciwpożarowej im. Józefa Tuliszkowskiego $\bigotimes$ Państwowego Instytutu Badawczego, rozdz. 2, https://www.cnbop.pl/ bip/2017/2017_05/2017.05.25-statut/statut_cnbop-pib_15-maja-2017.pdf (dostęp: 16.04.2019).

31 http://cmp-muzeum.pl/o-muzeum/informacje-ogolne/ (dostęp: 16.04.2019).

32 A. Warmiński, op. cit., s. 302.

${ }^{33}$ Ibidem.

Forum Socjologiczne 10, 2020

(C) for this edition by CNS 
3. dyskusja poborowa,

4. ocena możliwości psychicznych i fizycznych ${ }^{34}$.

W trakcie rekrutacji weryfikowane jest, czy rekrut nie ma wrodzonej akrofobii, czy umie pływać, jest sprawny i zręczny pod względem fizycznym. Dodatkowym atutem jest także dobry wzrok i słuch, aby dość szybko orientować się w terenie, na co składa się również rozwinięta spostrzegawczość.

Ocena cech psychicznych to zaopiniowanie możliwości przezwyciężenia licznych czynników, które są ogólnym modelem uciążliwości, wynikającym z pełnionej funkcji służbowej. Najważniejsza jest umiejętność zwalczania sytuacji stresogennych, gdyż służba w PSP może dostarczać ich wiele, a wszelka niepoprawność radzenia sobie z nimi może w efekcie doprowadzić do uaktywnienia się zespołu wypalenia zawodowego. Poniższa tabela zawiera istotne cechy fizyczne oraz psychiczne, jakimi powinien odznaczać się każdy strażak. Uwzględniono w niej aspekty odnoszące się do teorii wzoru osobowego członka grupy, zawierające w swej genezie aspekty fizyczne, kulturowe oraz moralne ${ }^{35}$.

Tabela 1. Pożądane cechy społeczne funkcjonariusza PSP

\begin{tabular}{|l|l|}
\hline \multicolumn{1}{|c|}{ Cechy psychofizyczne } & \multicolumn{1}{c|}{ Cechy kulturowe i moralne } \\
\hline wysoka wydolność organizmu & niekaralność \\
\hline szybkość i zwinność & poszanowanie obowiązujących norm \\
\hline logiczne myślenie, koncentracja & chęć niesienia pomocy \\
\hline siła, wytrzymałość & przestrzeganie kodeksu strażaka \\
\hline dobry wzrok, słuch & umiejętność pracy w zespole \\
\hline rozwinięty układ czuciowy i powonienia & zaufanie do przełożonych \\
\hline zrównoważenie emocjonalne & zaufanie do współpracowników \\
\hline samodzielność, stanowczość & nieposzlakowana opinia \\
\hline
\end{tabular}

Źródło: opracowano na podstawie Ministerstwo Spraw Wewnętrznych, Program nauczania nr 1/93 dla zawodu: technik pożarnictwa w Szkole Aspirantów Państwowej Straży Pożarnej. Załącznik nr 3 do zarządzenia nr 124 Ministra Spraw Wewnętrznych z dnia 15 grudnia 1993 roku, Warszawa 1993, s. 3.

J. Maciejewski podkreśla również, że bardzo ważnym elementem w pracy mundurowej strażaków jest chęć niesienia pomocy ${ }^{36}$. Funkcjonariusze PSP, jak wynika $z$ tekstu roty ślubowania strażaka, powinni być „ofiarni i mężni”, a niesiona przez nich pomoc społeczeństwu odbywa się nawet ze świadomością utraty

${ }^{34}$ http://prawo.sejm.gov.pl/isap.nsf/download.xsp/WDU19910880400/U/D19910400Lj.pdf (dostęp: 25.04.2019).

35 J. Maciejewski, op. cit., s. 91.

36 Ibidem, s. 124.

Forum Socjologiczne 10, 2020

(C) for this edition by CNS 
własnego życia ${ }^{37}$. Osoby mające poniżej $165 \mathrm{~cm}$ wzrostu, cierpiące na przewlekłe choroby, mające defekty fizyczne, choroby kręgosłupa, lęk wysokości i zaburzenia psychiczne nie mogą wykonywać tego zawodu ${ }^{38}$.

\section{Założenia metodologiczne badań własnych}

\subsection{Cel, problemy i hipotezy badawcze}

Po omówieniu historii i głównych zadań Państwowej Straży Pożarnej należy w części empirycznej wskazać główny cel pracy. Niniejsza analiza umożliwia zweryfikowanie głównych determinantów poziomu satysfakcji z pełnionej funkcji zawodowej przez funkcjonariuszy PSP. Jej głównym celem staje się analiza poziomu satysfakcji ze służby oraz permanentnie związane z nim czynniki, takie jak dodatkowa aktywność zawodowa czy ocena sytuacji materialnej. Ustanowiony cel umożliwił sformułowanie problemów i hipotez szczegółowych.

Problemy szczegółowe:

1. Jaki jest poziom satysfakcji z wykonywanej służby zawodowej i działalności prowadzonej przez PSP w opinii strażaków?

2. Czy i jakich dodatkowych aktywności zawodowych podejmują się funkcjonariusze?

3. Jak funkcjonariusze biorący udział w badaniu oceniają swoją obecną sytuację materialną?

Hipotezy szczegółowe:

1. Funkcjonariusze Państwowej Straży Pożarnej mają pozytywny stosunek do swojej pracy i systemu organizacyjnego PSP. Ponadto prestiż zawodu strażaka w opinii badanych jest wysoki.

2. Dyżurowy system zmianowy w PSP (24/48) umożliwia funkcjonariuszom podejmowania się dodatkowych aktywności zawodowych w celu osiągania wyższych zarobków z tytułu pracy. Strażacy prowadzą działalności gospodarcze, są zaangażowani w prace dorywcze o różnym charakterze lub udzielają się w sektorze pozarządowym.

3. Poziom płac w Państwowej Straży Pożarnej jest wyższy w porównaniu z zarobkami przeciętnego pracownika naszego kraju. Sytuacja materialna w opinii funkcjonariuszy jest zatem dobra.

$37 \mathrm{http} / /$ www.strazpozarna.info/ceremonial-i-tradycja/slubowanie-strazaka-psp.html (dostęp: 29.04.2019).

38 Ministerstwo Spraw Wewnętrznych, Program nauczania nr 1/93 dla zawodu: technik pożarnictwa w Szkole Aspirantów Państwowej Straży Pożarnej, Załącznik nr 3 do zarządzenia nr 124 Ministra Spraw Wewnętrznych z dnia 15 grudnia 1993 roku, Warszawa 1993, s. 3. 


\subsection{Metody i techniki badawcze oraz zastosowany dobór próby}

Badania zostały przeprowadzone zgodnie z metodologią badań społecznych i metodzie ilościowej poprzez wykorzystanie narzędzia badawczego, czyli ankiety własnego autorstwa. Zastosowana tu technika pozwoliła zachować pełną anonimowość respondentów, natomiast nie obligowała ona badacza do bezpośredniej obserwacji zjawisk zachodzących w strukturze PSP. Niektóre pytania zawarte w ankiecie dotyczyły bezpośredniej oceny przełożonych lub sfer osobistych badanych funkcjonariuszy.

W celu prawidłowego przeprowadzenia niniejszej analizy empirycznej wybrano dobór celowy ze względu na dość liczną populację badanej instytucji. Strażacy to specyficzna grupa społeczna wyróżniająca się na tle innych zawodów stopniem organizacyjnym, hierarchicznością, ubiorem służbowym, trybem odbywania zmian i dyżurów, obowiązkową dyspozycyjnością w każdy dzień tygodnia. Badania zostały przeprowadzone w kwietniu 2019 roku na stu funkcjonariuszach w dwóch jednostkach organizacyjnych Państwowej Straży Pożarnej (komendzie wojewódzkiej oraz komendzie miejskiej). Aby zachować reprezentatywność badań zastosowano również dobór kwotowy z uwzględnieniem następujących zmiennych niezależnych:

1. Płeć respondentów z uwzględnieniem niskiego odsetka kobiet w strukturach PSP - funkcjonariuszki stanowią niecałe $4 \%$ populacji strażaków ${ }^{39}$. W badaniu uczestniczyło 84 mężczyzn i 16 kobiet.

2. Poziom wykształcenia respondentów:

— średnie: $36 \%$,

- policealne: $11 \%$,

- wyższe: $53 \%$.

3. Pion służbowy, w którym funkcjonariusz jest zatrudniony: zarówno komenda wojewódzka, jak i miejska w swej strukturze organizacyjnej wyróżniała się szerokim pionem zatrudnienia:

- logistycznym: $10 \%$,

- szkoleniowym: $8 \%$,

- operacyjnym: $30 \%$,

- prewencyjnym: $11 \%$,

- finansowym: $7 \%$,

- interwencyjnym: $18 \%$,

- bojowym: $16 \%$.

\section{Analiza wyników badań}

Zawarte w ankiecie wskaźniki empiryczne umożliwią weryfikację problemów badawczych i hipotez roboczych. Ich treści odwołują się do ogólnej oceny satysfakcji

39 https://strazacki.pl/artykuły/kobiety-w-straży-pożarnej (dostęp: 21.05.2019). 
z pełnionej funkcji zawodowej, działalności PSP czy też ustosunkowania się do opinii społecznej na temat prestiżu wykowanego przez strażaków zawodu. Nie mniej ważne stają się również kwestie związane z sytuacją materialną respondentów, gdyż jest to czynnik istotny z punktu widzenia analizy poziomu satysfakcji z wykonywanej pracy zawodowej. Ponadto należy wskazać, czy funkcjonariusze biorący udział w badaniu są wystarczająco usatysfakcjonowani z kwestii zarobkowych w strukturach PSP, aby pomimo możliwości stwarzanych przez dyżurowy system pracy nie podejmować się dodatkowej aktywności zawodowej, która może mieć negatywny wpływ na ich poczucie zmęczenia i uaktywnienia się syndromu wypalenia zawodowego.

\subsection{Ocena poziomu satysfakcji strażaków z wykonywanego przez nich zawodu i działalności PSP}

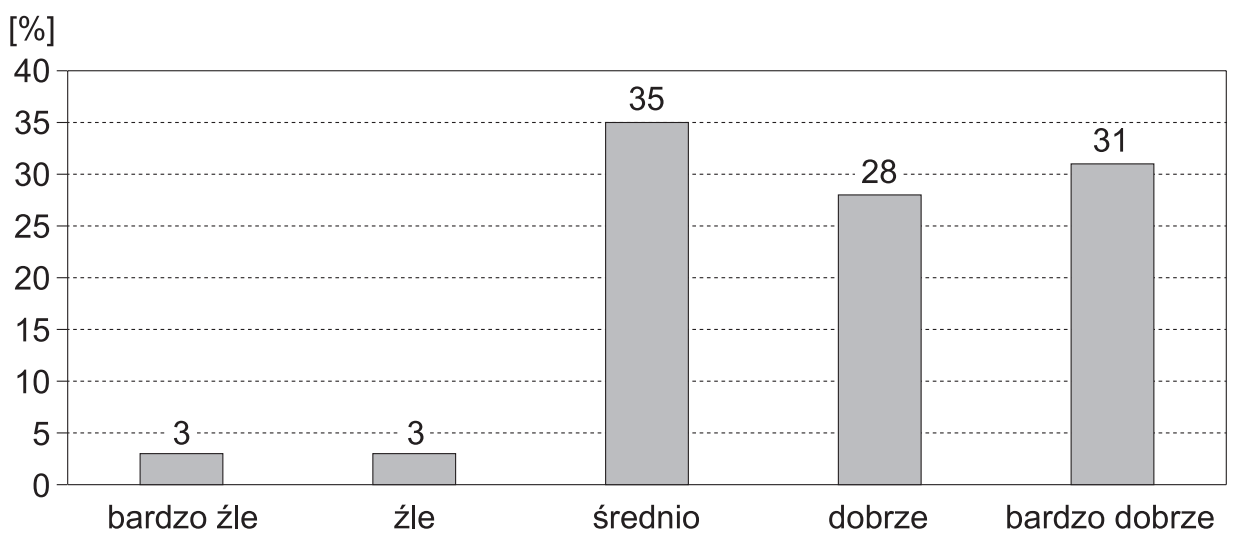

Wykres 2. Ogólna ocena działalności PSP przez respondentów

Źródło: badania własne.

Wykres wskazuje, że większość funkcjonariuszy pozytywnie oceniła komponenty organizacyjne Państwowej Straży Pożarnej (59\% — „dobrze” i „bardzo dobrze"). Najwięcej odpowiedzi w kryterium indywidualnym uzyskała odpowiedź "średnio" - 35\% respondentów. Ocena w stopniu bardzo złym i złym stanowi zdecydowaną mniejszość (6\% uzyskanych odpowiedzi) - wykres 2.

Postawione pytanie $\mathrm{w}$ ankiecie miało na celu dokonanie przez respondentów indywidualnej oceny poziomu satysfakcji z wykonywanych obowiązków zawodowych. Analiza wykazała, że najwięcej strażaków oceniło poziom satysfakcji w stopniu wysokim (48\%). Następnym co do ilości wybranego współczynnika jest ocena średnia (25\%). Tylko u 15\% badanych osób satysfakcja z pracy w PSP jest bardzo wysoka. Natężenie niskie (8\%) i bardzo niskie (4\%) uzyskały najmniejszą aprobatę respondentów. Ogólna średnia poziomu satysfakcji wszystkich respondentów wynosi 3,62 — pomiędzy natężeniem średnim a wysokim (wykres 3). 


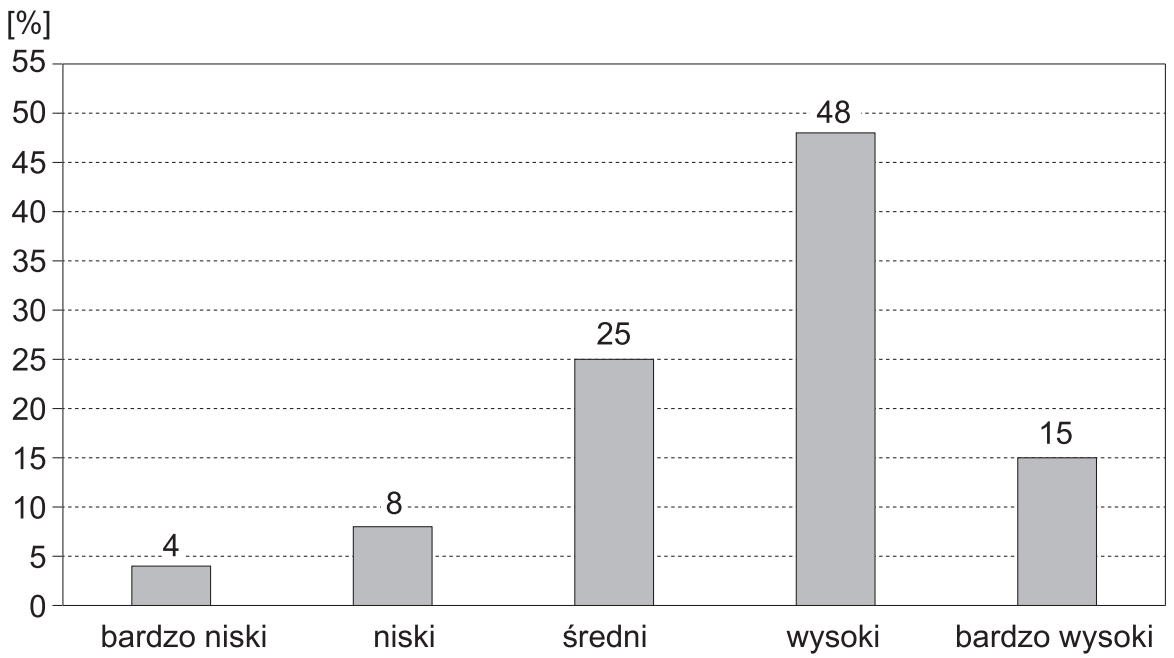

Wykres 3. Poziom satysfakcji z wykonywanej służby w PSP

Źródło: badania własne.

Tabela 2. Służba w PSP jako zawód prestiżowy

\begin{tabular}{|l|c|c|c|c|}
\cline { 2 - 5 } \multicolumn{1}{c|}{} & Częstość & $\%$ & \% ważnych & \% skumulowany \\
\hline zdecydowanie nie & 5 & 5 & 5 & 5 \\
\hline raczej nie & 11 & 11 & 11 & 16 \\
\hline ani tak, ani nie & 15 & 15 & 15 & 31 \\
\hline raczej tak & 42 & 42 & 42 & 73 \\
\hline zdecydowanie tak & 27 & 27 & 27 & 100 \\
\hline ogólem & 100 & 100 & 100 & \\
\hline
\end{tabular}

Źródło: badania własne.

Pojęcie prestiżu to ogólne określenie komponentów, spośród których możemy wyróżnić między innymi: opinię społeczną, system gratyfikacyjny, poczucie odgrywania roli społecznie pożądanej. Większość respondentów potwierdziła stawianą $\mathrm{w}$ niniejszej pracy hipotezę: prestiż zawodu strażaka $\mathrm{w}$ opinii badanych jest wysoki. Stopień wysoki będą stanowiły następujące odpowiedzi: „raczej tak” (42\%) i „zdecydowanie tak” (27\%) - razem 69\%. Tylko 16\% badanych całkowicie zaprzeczyło stawianej tezie: „raczej nie” (11\%), „zdecydowanie nie” (5\%). Środkowa część analizowanej tabeli sytuuje się na granicy 15\%. - tabela 2. Hipoteza pierwsza została potwierdzona - funkcjonariusze Państwowej Straży Pożarnej mają pozytywny stosunek do swojej pracy i systemu organizacyjnego PSP. Ponadto prestiż zawodu strażaka w opinii badanych jest wysoki. 


\subsection{Zjawisko dodatkowej aktywności zawodowej u funkcjonariuszy PSP}

Strażacy pełnią swe obowiązki podczas dyżurów trwających 24 godziny, a po zakończeniu swej zmiany otrzymują 48 godzin na odpoczynek. Opracowany system nieoficjalnie umożliwia funkcjonariuszom podejmowanie się dodatkowej aktywności zawodowej w celu polepszenia własnej sytuacji materialnej. Uznałem, że dodatkowe aktywności zawodowe mogą wystąpić na dwóch następujących płaszczyznach, które zostały uwzględnione w trakcie procesu badawczego:

- działalności odpłatnej lub działalności charytatywnej,

— działalności związanej lub niezwiązanej statutowo z PSP.

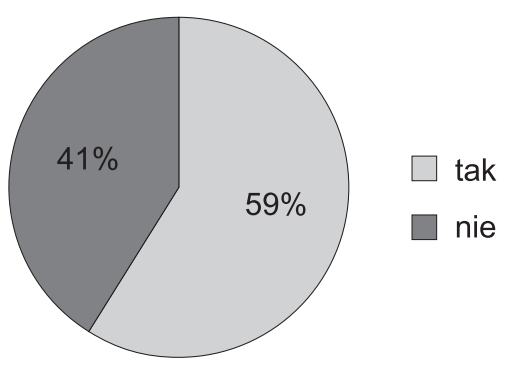

Wykres 4. Odsetek respondentów podejmujących się dodatkowej aktywności zawodowej

Źródło: badania własne.

Ponad połowa (59\%) respondentów podejmuje się dodatkowej aktywności zawodowej. Druga część funkcjonariuszy (41\%) zaznaczyła, że nie prowadzi dodatkowej działalności zarobkowej lub charytatywnej, zatem nie będą istotą rozważań w następnych pytaniach dotyczących analizowanego problemu badawczego (wykres 4).

Tabela 3. Rodzaj dodatkowej aktywności zawodowej respondentów

\begin{tabular}{|l|r|r|c|c|}
\cline { 2 - 5 } \multicolumn{1}{c|}{} & Częstość & $\%$ & $\%$ ważnych & \% skumulowany \\
\hline nie dotyczy & 41 & 41 & 41 & 41 \\
\hline zarobkowy & 58 & 58 & 58 & 99 \\
\hline niezarobkowy & 1 & 1 & 1 & 100 \\
\hline ogółem & 100 & 100 & 100 & \\
\hline
\end{tabular}

Źródło: badania własne.

Spośród 59 funkcjonariuszy podejmujących się dodatkowej aktywności zawodowej 99\% potwierdziło, że ich celem jest działalność o podłożu zarobkowym. Tylko jedna osoba jest zaangażowana $\mathrm{w}$ działalność charytatywną. Zakodowane odpowiedzi w rubryce „nie dotyczy” to respondenci zatrudnieni wyłącznie w strukturze PSP (tabela 3). 
Tabela 4. Wpływ dodatkowej aktywności zawodowej na stan materialny badanych funkcjonariuszy

\begin{tabular}{|l|r|r|r|c|}
\cline { 2 - 5 } \multicolumn{1}{c|}{} & Częstość & $\%$ & \% ważnych & \% skumulowany \\
\hline nie dotyczy & 41 & 41 & 41,4 & 41,4 \\
\hline ani tak, ani nie & 7 & 7 & 7,1 & 48,5 \\
\hline raczej tak & 25 & 25 & 25,3 & 73,7 \\
\hline zdecydowanie tak & 26 & 26 & 26,3 & 100 \\
\hline ogółem & 99 & 99 & 100 & \\
\hline braki danych & 1 & 1 & & \\
\hline ogółem & 100 & 100 & & \\
\hline
\end{tabular}

Źródło: badania własne.

Aż 87,94\% funkcjonariuszy wykazujących chęć działalności w obszarze dodatkowej aktywności zawodowej potwierdziło, że „drugi etat” ma znaczący wpływ na ich sytuację materialną („,zdecydowanie tak” i „raczej tak”). Respondenci niezdecydowani (,ani tak, ani nie”) to $12,06 \%$ badanej populacji. W pytaniu wystąpiły braki danych o łącznej wartości liczbowej: jedna osoba (tabela 4).

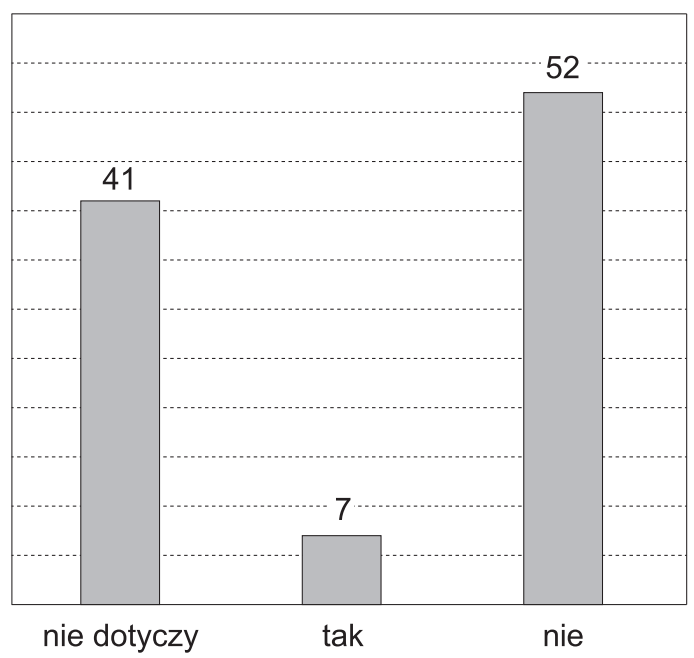

Wykres 5. Zależność dodatkowej aktywności zawodowej z obowiązkami w PSP

Źródło: badania własne.

Z poprzednich wykresów i tabel wynika, że ponad połowa funkcjonariuszy podejmuje się dodatkowych aktywności zawodowych. Znamienną kwestią jest weryfikacja, czy zatrudnienia te są $\mathrm{w}$ jakiś sposób powiązane $\mathrm{z}$ obowiązka$\mathrm{mi}$, jakie funkcjonariusze pełnią w paramilitarnej grupie dyspozycyjnej (chociażby ze względu na przydatność nabytych kompetencji do struktur PSP). W celu

Forum Socjologiczne 10, 2020

(C) for this edition by CNS 
uzmysłowienia sobie tej sytuacji przytoczmy następujący przykład: ogniomistrz $\mathrm{z}$ wykształcenia jest specjalistą do spraw BHP i tym sposobem prowadzi dodatkowe szkolenia dla funkcjonariuszy, czyli w samej instytucji jest jakby „podwójnie" zatrudniony.

Tylko 11,87\% respondentów prowadzi dodatkową działalność zarobkową, która jest jednocześnie $\mathrm{w}$ jakiś sposób związana $\mathrm{z}$ systemem organizacyjnym PSP. Zdecydowana większość respondentów $(88,13 \%)$ wykazuje swą aktywność na innym polu zawodowym (wykres 5).

Tabela 5. Rodzaj prowadzonej przez funkcjonariuszy dodatkowej aktywności zawodowej

\begin{tabular}{|l|c|c|c|c|}
\cline { 2 - 5 } \multicolumn{1}{l|}{} & Częstość & $\%$ & \% ważnych & \% skumulowany \\
\hline nie dotyczy & 41 & 41 & 41 & 41 \\
\hline $\begin{array}{l}\text { pracuję w jednostkach organizacyjnych } \\
\text { związanych statutowo z PSP }\end{array}$ & 2 & 2 & 2 & 43 \\
\hline prowadzę działalność gospodarczą & 17 & 17 & 17 & 60 \\
\hline $\begin{array}{l}\text { nie prowadzę działalności gospodarczej, } \\
\text { ale samodzielnie wykonuję zlecenia }\end{array}$ & 12 & 12 & 12 & 72 \\
\hline $\begin{array}{l}\text { pracuję dodatkowo w firmie } \\
\text { w mniejszym wymiarze czasowym }\end{array}$ & 22 & 22 & 22 & 94 \\
\hline pracuję u znajomego/znajomej & 4 & 4 & 4 & 98 \\
\hline $\begin{array}{l}\text { jestem zaangażowany w działalność } \\
\text { pozarządową }\end{array}$ & 2 & 2 & 2 & 100 \\
\hline ogółem & 100 & 100 & 100 & \\
\hline
\end{tabular}

Źródło: badania własne.

Spośród 59 osób podejmujących się dodatkowej aktywności zawodowej najwięcej respondentów zaznaczyło, że pracuje dodatkowo w innej firmie, lecz w mniejszym wymiarze czasowym, na przykład na pół etatu (37,29\%). Nieco mniej, ponieważ $28,81 \%$, funkcjonariuszy prowadzi swoją działalność gospodarczą oraz 20,33\% nie odprowadza stosownych składek do budżetu państwowego, ale wykonuje dodatkowe zlecenia, które mieszczą się w obrębie kompetencji zawodowych; $6,78 \%$ badanych wykazało, że dodatkowo pracuje u znajomego/znajomej, a jedyne 3,39\% jest dodatkowo zaangażowana w działalność mieszczącą się w obrębie struktur Państwowej Straży Pożarnej; 6,78\% strażaków pracuje na rzecz działalności pozarządowej (stowarzyszenia, fundacje) - tabela 5.

Niniejsze zestawienie tabelaryczne potwierdza, że badani respondenci najczęściej podejmują się dodatkowej pracy zarobkowej niezwiązanej z pełnionymi na co dzień obowiązkami strażaka. Poczyniona analiza potwierdziła hipotezę, która zakładała, że funkcjonariusze PSP korzystają z możliwości uzyskiwania wyższych dochodów miesięcznych poprzez dodatkową aktywność zawodową. Strażacy 
prowadzą działalności gospodarcze, są zaangażowani w prace dorywcze lub realizują się w strukturach pozarządowych.

\subsection{Ocena sytuacji materialnej strażaków}

Tabela 6. Ocena zarobków w PSP

\begin{tabular}{|l|c|c|c|c|}
\cline { 2 - 5 } \multicolumn{1}{c|}{} & Częstość & $\%$ & \% ważnych & \% skumulowany \\
\hline zdecydowanie nie & 33 & 33 & 33 & 33 \\
\hline raczej nie & 35 & 35 & 35 & 68 \\
\hline ani tak, ani nie & 19 & 19 & 19 & 87 \\
\hline raczej tak & 13 & 13 & 13 & 100 \\
\hline ogółem & 100 & 100 & 100 & \\
\hline
\end{tabular}

Źródło: badania własne.

Na postawione pytanie: czy zarobki w PSP są adekwatne do wykonywanych obowiązków służbowych, zdecydowana większość respondentów odpowiedziała zaprzeczeniem: 68\% („zdecydowanie nie”-33\%, „raczej nie” - 35\%). Pośrednią możliwość w ankiecie wybrało 19\% respondentów, a jedynie 13\% uważa, że ich zarobki są adekwatne w stosunku do pełnionej przez nich funkcji zawodowej (tabela 6). Uczestniczący w badaniu funkcjonariusze nie są zadowoleni $z$ obecnego systemu wynagrodzeń w PSP.

Tabela 7. Ocena sytuacji materialnej strażaków

\begin{tabular}{|l|c|c|c|c|}
\cline { 2 - 5 } \multicolumn{1}{c|}{} & Częstość & $\%$ & \% ważnych & \% skumulowany \\
\hline bardzo źle & 1 & 1 & 1 & 1 \\
\hline źle & 7 & 7 & 7 & 8 \\
\hline średnio & 50 & 50 & 50 & 58 \\
\hline dobrze & 41 & 41 & 41 & 99 \\
\hline bardzo dobrze & 1 & 1 & 1 & 100 \\
\hline ogólem & 100 & 100 & 100 & \\
\hline
\end{tabular}

Źródło: badania własne.

Połowa badanych strażaków wskazała, że jest średnio zadowolona ze swojej obecnej sytuacji materialnej (50\%). Wysoki stopień procentowy uzyskało natężenie współczynnika o wartości 4 („dobrze”): 41\%; 7\% funkcjonariuszy wskazało, że ich sytuacja materialna jest zła, a $2 \%$ to dwie najbardziej przeciwstawne sobie wartości natężenia („bardzo źle” - 1\%, „bardzo dobrze” - 1\%) — tabela 7. 


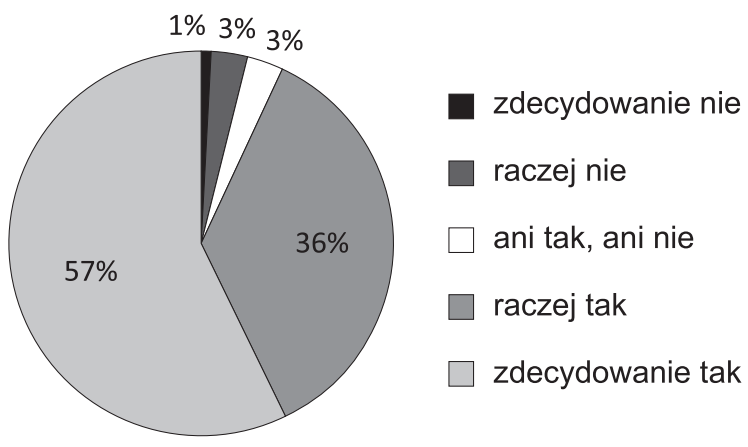

Wykres 6. System gratyfikacyjny w strukturach PSP

Źródło: badania własne.

Ukazaną problematykę dodatkowej aktywności zawodowej dopełni analiza kwestii zmian, jakie powinny zostać zastosowane w systemie finansowym PSP. Aż 93\% respondentów opowiedziało się za modyfikacją lub ogólnym wprowadzaniem gratyfikacji pieniężnych, innych nagród lub zwiększenia wypłacanych dotychczas premii za zasługi zawodowe. Tylko 3\% funkcjonariuszy nie było zdecydowanych i wybrało odpowiedź ,ani tak, ani nie” i raczej nie zgodziło się z proponowanym założeniem (3\% - „raczej nie”). Najmniejszą liczbę uzyskała adnotacja „zdecydowanie nie" - $1 \%$ (wykres 6). Można zatem przypuszczać, że strażacy mimo zdecydowanego wskazania poziomu prestiżu swojego zawodu nie są jednak zadowoleni z obecnego systemu gratyfikującego. Hipoteza trzecia nie została potwierdzona poziom płac w Państwowej Straży Pożarnej jest wyższy w porównaniu z zarobkami przeciętnego pracownika naszego kraju. Sytuacja materialna w opinii funkcjonariuszy jest zatem dobra.

\section{Podsumowanie i wnioski}

Państwowa Straż Pożarna jest paramilitarną grupą dyspozycyjną o bogatej, lecz zawiłej historii. W strukturze PSP zatrudnieni są odważni i gotowi do poświęceń funkcjonariusze. Ich celem jest zapewnienie bezpieczeństwa społeczności lokalnej (mikrostruktura) oraz całemu społeczeństwu (makrostruktura), często poprzez niełatwe i permanentnie rozwijające się akcje ratownicze zagrażające ich zdrowiu.

Przeprowadzone badania dowodzą, że czynni zawodowo funkcjonariusze Państwowej Straży Pożarnej mimo wszystko ukazują pozytywne strony instytucji, w której pracują. Ogólna ocena działalności PSP oraz stopień wykazywanej podczas służby efektywności jest na wysokim poziomie $-\mathrm{z}$ pewnością jest to sukces dla naczelnej kadry dowódczej niniejszej grupy dyspozycyjnej. Założenia prowadzonych wcześniej debat publicznych i badań opinii społecznej potwierdziły tezę, że w mniemaniu zarówno społeczeństwa, jak i samych strażaków prestiż wykonywanego przez 
nich zawodu jest z natury rzeczy gwarancją opierającą swe założenia na autorytecie społecznym.

Wątpliwą kwestią są jednak gratyfikacje finansowe oraz cały system ekonomiczny struktury Państwowej Straży Pożarnej, ponieważ według respondentów ich zarobki są relatywnie niskie. Dyżurowy system pracy w PSP nieoficjalnie umożliwia strażakom podejmowanie się dodatkowej aktywności zawodowej, z której badani strażacy korzystają i powiększają budżet domowy, zatrudniając się w innej firmie w mniejszym wymiarze czasowym, prowadząc działalności gospodarcze oraz wykonując zlecenia o charakterze zarobkowym. Aktywność ta jest jednak nader rzadko związana z określonymi statutowo celami instytucji do walki z ogniem. Warto rozważyć tę kwestię i podjąć działania zmierzające do reorganizacji systemu finansowego jednostek zatrudnionych w PSP.

\section{Bibliografia}

Burzyński E., Radwański Z., Dzieje ochrony przeciwpożarowej w Polsce, Warszawa 1964.

Falecki D., Zarys rozwoju ochrony przeciwpożarowej w Polsce do 1992 r., [w:] Czerwona księga pożarów, t. 1, red. P. Guzewski, D. Wróblewski, Józefów 2016.

Maciejewski J., Grupy dyspozycyjne - analiza socjologiczna, Wrocław 2012.

Maslow A., Motywacja i osobowość, przeł. J. Radzicki, red. T. Rzepa, Warszawa 2009.

Kowalski M., Wróblewski D., Działalność badawczo-rozwojowa w funkcji realizacji misji, wizji i strategii rozwoju PSP, [w:] Bezpieczeństwo i technika pożarnicza, t. 4, red. M. Kowalski, D. Wróblewski, Józefów 2012.

Popis J., Historia pożarnictwa w Polsce, [w:] Kultura bezpieczeństwa. Nauka - praktyka - refleksje, red. Y. Boshytskyi et al., Kraków 2013.

Prokopp M., Historia bezpieczeństwa ogniowego w Królestwie Polskim w latach 1831-1855, Warszawa 1934.

Riegert D., Strzyżewska M., Państwowa Straż Pożarna, [w:] Czerwona księga pożarów: wybrane problemy pożarów oraz ich skutków, red. P. Guzewski, D. Wróblewski, Józefów 2016.

Socha R., Sulenta S., Zarządzanie kryzysowe a działania międzynarodowe Państwowej Straży Pożar$n e j$, ,Zeszyty Naukowe Politechniki Śląskiej Seria Organizacja i Zarządzanie” 2016, z. 87.

Stochmal M., Funkcjonariusze Państwowej Straży Pożarnej w świetle badań socjologicznych, „Zeszyty Naukowe SGSP" 2013, nr 48(4).

Warmiński A., Zadania i organizacja Państwowej Straży Pożarnej w zakresie ochrony przeciwpożarowej, „Doctrina: Studia społeczno-polityczne” 2009, nr 6.

\section{Akty prawne}

Ministerstwo Spraw Wewnętrznych, Program nauczania nr 1/93 dla zawodu: technik pożarnictwa w Szkole Aspirantów Państwowej Straży Pożarnej, Załącznik nr 3 do zarządzenia nr 124 Ministra Spraw Wewnętrznych z dnia 15 grudnia 1993 roku, Warszawa 1993.

Regulamin organizacyjny Komendy Wojewódzkiej Państwowej Straży Pożarnej we Wrocławiu, http://bip.straz.wroclaw.pl/index.php?id=207 (dostęp: 14.04.2019).

Rozporządzenie Prezesa Rady Ministrów z dnia 15 września 1999 roku w sprawie nadania statutu Komendzie Głównej Państwowej Straży Pożarnej (Dz.U. Nr 75, poz. 842 i 843), http://prawo. sejm.gov.pl/isap.nsf/DocDetails.xsp?id=WDU19990750843 (dostęp: 13.04.2019). 
Rozporządzenie Ministra Spraw Wewnętrznych i Administracji z dnia 15 maja 2017 roku w sprawie zatwierdzenia statutu Centrum Naukowo-Badawczego Ochrony Przeciwpożarowej im. Józefa Tuliszkowskiego - Państwowego Instytutu Badawczego, https://www.cnbop.pl/ bip/2017/2017_05/2017.05.25-statut/statut_cnbop-pib_15-maja-2017.pdf (dostęp: 16.04.2019).

Ustawa z dnia 24 sierpnia 1991 roku o Państwowej Straży Pożarnej (Dz.U. z 1991 r. Nr 88, poz. 400), http://prawo.sejm.gov.pl/isap.nsf/download.xsp/WDU19910880400/U/D19910400Lj.pdf (dostęp: 10.04.2019).

\section{Źródła internetowe}

Biuletyn Informacyjny Państwowej Straży Pożarnej za rok 2017, s. 11, https://www.straz.gov.pl/aktualnosci/biuletyny (dostęp: 15.04.2019).

http://cmp-muzeum.pl/o-muzeum/informacje-ogolne/ (dostęp: 16.04.2019).

http://www.kmpspruda.pl/zadania (dostęp: 15.04.2019).

https://www.straz.gov.pl/kontakt/szkoly_pozarnicze (dostęp: 16.04.2019).

http://straz.wroclaw.pl/bezpieczne-pogranicze/ (dostęp: 10.04.2019).

https://strazacki.pl/artykuły/kobiety-w-straży-pożarnej (dostęp: 21.05.2019).

\section{Analysis of the professional situation of officers of the State Fire Service}

\section{Summary}

The sense of security is one of humanity's main needs. Despite the development of civilization and progressing urbanization, units are exposed to many threats that must be effectively eliminated by dispositional groups of Polish society and their professionally prepared staff. The author characterizes the State Fire Service, which is a paramilitary formation of the state security system. He shows a rich but complicated history and then describes the social model of the firefighter. The second part is the analysis of quantitative research. The author verifies the level of satisfaction of firefighters based on their professional role.

Keywords: state fire brigade, dispositional groups, paramilitary dispositional groups, sociology of dispositional groups, work sociology 